\title{
The Impact of Pre-service Teachers' Pedagogical Beliefs on Teaching Science as Inquiry: A Silent Antagonist for Effective Inquiry-Based Science Lessons
}

\author{
Witchayada Nawanidbumrung ${ }^{1}$, Sara Samiphak ${ }^{2 *}$, Noriyuki Inoue ${ }^{3}$ \\ ${ }^{1}$ Human Informatics and Cognitive Sciences, Faculty of Human Sciences, Waseda University, Tokorozawa, Japan. ${ }^{2}$ Department of Curriculum and \\ Instruction, Faculty of Education, Chulalongkorn University, Bangkok, Thailand. ${ }^{3}$ Human Informatics and Cognitive Sciences, Faculty of Human \\ Sciences, Waseda University, Tokorozawa, Japan
}

*Corresponding Author: sara.s@chula.ac.th

\section{ABSTRACT}

Teachers' beliefs are strong predictors of their practices. They guide how teachers understand the implementation of effective inquirybased lessons. The cross-case analysis indicated that the fundamental problems observed in many Thai pre-service science teachers' classroom inquiries stemmed from their beliefs on teaching science. Although the teachers agreed on the importance of having students engage in scientific inquiry through hands-on activities, they believed that its purpose was to help students' sense-making of what the teachers told them. They believed an emphasis should be placed on asking as many knowledge questions as they would like, providing answers, giving procedural instructions to students, and offering specifics of what students should observe in the hands-on activities. The teachers believed that these were effective avenues to help students gain scientific knowledge in terms of concrete experiences. The observed lessons evidenced that teachers failed to elicit students' interest, curiosity, and engagement in inquiry lessons. This study suggests that pre-service teachers' benefits from being provided with real-world opportunities to reflect on their educational beliefs and get suitable supports to transform their beliefs for delivering inquiry-based science lessons.

KEY WORDS: Teacher's belief; inquiry-based teaching; pre-service teacher; teaching science; science lessons

\section{INTRODUCTION}

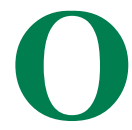

ver the past decades, inquiry-based teaching has been emphasized in science education as a fundamental approach for the effective teaching of science. As is often the case in many countries, science education reform in Thailand has focused on the need to foster science teachers to shift from the traditionally lecture-based model to the inquirybased teaching model, hence allowing students to construct new knowledge through self-directed investigations (National Research Council, 1996; Krajcik, 2015). The purpose of implementing the inquiry-based science lesson is to motivate students to engage in thinking processes as "professional scientists" (National Research Council, 1996, 2000; Sandoval and Reiser, 2004; Minner et al., 2010). These processes help them come to understand scientific concepts deeply and develop their scientific abilities in personally meaningful ways (National Research Council, 2000; Capps and Crawford, 2013).

Even though numerous empirical studies underlined the significance of inquiry-based teaching in science education, many researchers have found that science teachers, especially pre-service teachers, faced various challenges in teaching science as inquiry and had tendencies to implement inquirybased pedagogy in quite ineffective manners (Keys and Bryan 2001; Kang et al., 2013). For instance, with their fears of out-of-control classrooms, teachers' demonstrations merely simulate scientific inquiry, or teachers may manipulate science lessons to obtain the expected results (Kuhn, 1993; Nott and Smith, 1995).

Looking more closely, researchers suggested that teaching practices are significantly influenced by what teachers believe effective teaching is about (Tondeur et al., 2017; Muhtarom et al., 2019). Nespor (1987) defined that a belief system, unlike a knowledge system, is based on individual judgment and evaluation - it does not require a truth condition and cannot be evaluated as right or wrong. Tatar (2015) pointed that even if the importance of inquiry-based teaching is conveyed in teacher education programs, novice teachers still believed in the traditional approach of teaching that teachers are at the center of classroom, struggled to design and implement inquiry lessons, and failed to elicit students' knowledge construction. There is quite a disconnect between what is learned in teacher education and what is done in real classrooms.

The transition from more traditionally lecture-based instructions to more constructivist instructions is not easy to achieve, as it requires a significant change in their beliefs (Crawford, 2007). To promote the implementation of effective inquiry lessons, science teachers must reflect on their beliefs and gain competencies that support this process. To respond to 
this concern, the question is, how do novice teachers actually teach inquiry-based lessons in their science classrooms? What kinds of beliefs do they hold in teaching inquiry lessons? Answering these questions are essential since they provide guidance on how to develop science teacher training programs.

\section{LITERATURE REVIEW}

An inquiry-based science lesson is described to be a multifaceted activity that stresses the significance of boosting students' engagement in their learning experiences through the development of both hands-on and mind-on skills - thinking processes (National Research Council, 2000). National Science Education Standard (National Research Council, 2000) suggested that the key to actualizing this development process effectively is to support scientific inquiry in the science classrooms, which consists of the following features:

\section{Engaging in a Scientifically Oriented Question}

Science lessons start with asking a scientifically oriented question - the leading question guiding inquiry procedureswhich typically centers on objects, organisms, and events in the natural world. Teachers play an active role in identifying guiding questions, and the questions should be meaningful and relevant to students, in reference to their interest, curiosity, and naïve concepts in science (Windschitl et al., 2012; Lederman et al., 2014).

\section{Making Inquiries and Giving Priority to Evidence in Responding to Questions}

Teachers have students engage in the direct experiences and practices with the process of inquiry - which consists of observation, data collection, reflection, and analysis of firsthand events and phenomena.

\section{Communicating, Discussing, and Justifying their Discoveries with Others}

Teachers push students to share and exchange their results with others, such as initiating a whole-class discussion - where students can ask questions, examine the evidence, identify faulty reasoning, or suggest alternative explanations for the same observational data in a collaborative manner. This cultivates them to construct their own scientific understanding (Lampert, 2001). Teachers serve as facilitators for dialogue so as to help students consider the cogency, relationship, order, and theorizing of the results (Inoue et al., 2019).

\section{Drawing an Evidence-based Explanation}

Teachers have students use the evidence to formulate an explanation in order to address scientifically oriented questions.

\section{Connecting Explanations to Scientific Knowledge}

Teachers encourage students to deeply consider the underlying concepts and make associations to the scientifically accurate explanations (Windschitl et al., 2018).

However, facilitating scientific inquiry in science lessons requires further consideration. National Research Council (1996) stated that effective implementation of inquiry lessons requires the teacher to match their actions to students' particular needs. It is balancing the tension between allowing students to pursue an interest and curiosity in science and to meet their own goals, and the teacher's need to move on to the planned lessons. Being able to support students' meaningful inquiries, the teacher requires flexibility in decision-making and actions.

Research has pointed out the relevance of teachers' beliefs for implementing inquiry lessons in the classroom (Saad and BouJaoude, 2012). These beliefs play a crucial role in directing how they design their inquiry-based lessons through the process of selecting learning theories and instructional strategies they think are "the best" for them and their students (National Research Council, 1996; Tondeur et al., 2017). Thus, if teachers believe in the effectiveness of traditional approach over inquiry-based approach and consider teaching as a process of memorizing and recalling imparted knowledge, they will act as mere knowledge transmitters (Antoniadou and Skoumios, 2012; Hansen et al., 2015).

\section{METHODOLOGY}

\section{Context of the Study}

The participants comprised six Thai pre-service teachers who were in their final year of a 5-year teacher preparation program. This program aimed to prepare teachers for employment as secondary school science teachers who could implement inquiry-based teaching as the foundation of science lessons. Therefore, they were required to engage in two major portions of the program: learning the science content, in their $1^{\text {st }}$ and $2^{\text {nd }}$ year, theories and instructional strategies in their $3^{\text {rd }}$ and $4^{\text {th }}$ year with an occasional chance of practicing inquiry-based activities through coursework; and a teaching practicum (student-teaching) in schools in their final year.

Five out of six pre-service teachers were females. All of them were enrolled in a double-major program, but they were diverse in sub-majors or subjects and grade levels they were teaching. The demographics of the participants are shown in Table 1. To maintain anonymity, the actual names of participants are withheld; pseudonyms were used.

\section{Data Collection}

Before collecting data, ethical approval from the institutional review board of the university supervising research was obtained. All participants read an informed consent and

\begin{tabular}{llll}
\hline \multicolumn{2}{l}{ Table 1: Demographic data of participants } \\
\hline Participants & Gender & \multicolumn{2}{c}{ Subject and Grade Level of Teaching } \\
\cline { 3 - 4 } & & $\begin{array}{l}\text { Lower secondary } \\
\text { school students }\end{array}$ & $\begin{array}{l}\text { Upper secondary } \\
\text { school students }\end{array}$ \\
\hline Teacher Chang & Male & Science Grade 7 & Chemistry Grade 11 \\
Teacher Nok & Female & Science Grade 8 & Biology Grade 10 \\
Teacher Kai & Female & Science Grade 8 & Biology Grade 11 \\
Teacher Pla & Female & Science Grade 8 & Chemistry Grade 11 \\
Teacher Maew & Female & Science Grade 9 & Chemistry Grade 11 \\
Teacher Kung & Female & Science Grade 9 & Chemistry Grade 10 \\
\hline
\end{tabular}


voluntarily agreed to participate before setting up classroom visits. In the data collection process, we first conducted a preinterview with each teacher regarding what they think about effective science teaching, according to the questions shown in Table 2.

This pre-interview was divided into two major parts: belief questions and video-tape case questions. The belief questions were used to study all participants' existing beliefs through their responses to the planned questions, while the videotape case questions were required to conjecture their beliefs through their analysis of a case study in the video clip. To understand teachers' beliefs in Thai context, a video clip of Thai science classroom provided by the Office of Basic Education Commission of Thailand was used in this study. In conducting the interview, we followed the methodological principles of clinical interviews (Ginsburg, 1997), such as asking follow-up questions and requesting examples about anything that seemed to require further clarifications. This is to help interviewees reflect on their beliefs as much as possible. Each pre-interview including two sections lasted about $40-45 \mathrm{~min}$.

After the pre-interview was completed, we made the arrangements for classroom observation based on the schedules of teachers' lessons and their schools. They were asked to provide the date/time of what they called inquiry-based science lessons that they would like the research team to observe, and the research team selected from those availability. The teachers provided us with lesson plans beforehand. The first author set up a video camera to capture the sessions. We observed 3 lessons per teacher. Each lesson was between 50-100 min, depending on the schedule of their lessons. After finishing observing each lesson, we conducted a post-interview

\begin{tabular}{|c|c|}
\hline Section & Dimensions \\
\hline \multirow{6}{*}{$\begin{array}{l}\text { Belief } \\
\text { questions }\end{array}$} & 1. In your opinion, what is the goal of science education? \\
\hline & $\begin{array}{l}\text { 2. In your opinion, what are the characteristics of an } \\
\text { effective science teacher? }\end{array}$ \\
\hline & $\begin{array}{l}\text { 3. In your opinion, what are the characteristics of effective } \\
\text { learners/students in science classrooms? }\end{array}$ \\
\hline & $\begin{array}{l}\text { 4. In your opinion, what is the best way to effectively teach } \\
\text { science? }\end{array}$ \\
\hline & $\begin{array}{l}\text { 5. In your opinion, how do the learners/students effectively } \\
\text { learn science? }\end{array}$ \\
\hline & $\begin{array}{l}\text { 6. In your opinion, what does it take to know when the } \\
\text { students' learning processes occurred? }\end{array}$ \\
\hline \multirow{6}{*}{$\begin{array}{l}\text { Video-taped } \\
\text { case } \\
\text { questions }\end{array}$} & $\begin{array}{l}\text { 1. If you were to teach this topic/lesson, what would be } \\
\text { your students' learning goal? }\end{array}$ \\
\hline & 2. What do you think about this science teacher? \\
\hline & 3. What do you think about these students? \\
\hline & $\begin{array}{l}\text { 4. What do you think about science teaching in this } \\
\text { classroom? }\end{array}$ \\
\hline & $\begin{array}{l}\text { 5. Do you think these students were learning science } \\
\text { effectively? Why? }\end{array}$ \\
\hline & $\begin{array}{l}\text { 6. Do you think the learning process occurred in this } \\
\text { classroom? Why? }\end{array}$ \\
\hline
\end{tabular}

with them around 15-20 min; this interview was based on determining what the participants thought was successful or unsuccessful in each lesson. The post-interview reflective questions are represented in Table 3.

To investigate teachers' beliefs, not merely their understanding, we looked for the evidence of the teachers stating their beliefs. For example, "Although inquiry lessons require students to learn by doing, students' final understanding depends on teacher's explanation" - this statement would be considered as belief, not understanding since it indicated participants' value system and personal judgment on what effective teaching is about.

\section{Data Analysis}

The interviews were analyzed using qualitative content analysis and interpreted in the light of the five essential features of inquiry outlined by the National Research Council (2000). The analysis consisted of the following three steps. We first searched for pre-service teachers' beliefs on teaching inquirybased lessons made visible through their interview responses. In this step, common themes were tentatively extracted, and sub-categories were created. Then, for the $2^{\text {nd }}$ step, the videotaped class sessions were analyzed to synthesize more detailed pictures of what all participants tried out in their actual classrooms. In this $2^{\text {nd }}$ step, in order to determine what they struggled in their inquiry-based teaching, we looked for presence or absence of each feature of teaching inquiry-based science lessons in the observed lessons and lesson plans using the framework of the five essential features of inquiry (National Research Council, 2000). In the final step, the key aspects of their inquiry-based lessons were uncovered as we holistically examined their interview responses and videotaped class sessions in iterative cycles, and built consensus among us regarding the final themes. Eventually, the following key themes were extracted.

\section{FINDINGS}

Based on the analyses of the interviews and class observations, we found that all pre-service teachers agreed on the importance of inquiry-based lessons, but many of their classroom lessons had fundamental problems from an inquiry-based lesson point of view. The interviews with the teachers revealed that their belief system on science teaching seemed to underlie these problems.

\section{Table 3: Post-interview reflective question protocol}

\section{Dimensions}

1. What do you think about your roles as a science teacher today?

2. What do you think about the students in your classroom today?

3. Do you think that this lesson could help students learn science effectively? How? Which step was essential to your students' learning science?

4. What things that you think were successful and unsuccessful in your today lesson? 
Pre-service Teachers Believed that Asking Students Knowledge Questions to Help them Recall the Knowledge is Good Enough to Establish New Inquiries even Though it may Discourage them from Exploring New Knowledge with a Sense of Interest and Curiosity in Science

The research findings indicated that at the beginning of many pre-service teachers' lessons, they usually asked students with knowledge questions of the previous lessons. This is done without encouraging the students to think about leading questions for the new lessons they are about to learn, i.e., no scientifically oriented question (first feature of an inquirybased science lesson). When we interviewed the teachers, they often stated that having their students recall the previously learned knowledge to confirm the students' academic success in previous lessons is adequate to start new inquiries.

A representative example of this took place at the beginning of Teacher Pla's lesson on nutrition. She began her lessons by asking, "Do you still remember what we studied last week?" This was followed by the review questions "How many calories is $1 \mathrm{~g}$ of carbs?" "Which solution is used to test the presence of starch?" and "Which vitamins are fatsoluble?" After providing right or wrong judgments to students' responses and gave them the right answers, she proceeded to new hands-on work by explaining what she wanted students to do in the next activity - without getting them interested or curious about the topic. Here, although she gave a review problem from the previous class, she did not pose another question or have students engage in a scientifically oriented question. Instead, the questions she asked at the beginning of the class merely demanded students to recall facts rather than activating students' prior knowledge needed for new inquiries. Consequently, we conjectured that her students did not seem to be convinced into new inquiries.

Through the interview with Teacher Pla, it seemed that her instructional practices originated from her belief "The teacher should ask what they studied in the previous class before explaining the new experiment. This also helps me confirm whether my last class was successful or not, " said the teacher. This implies that she seemed to believe that her question-andanswer interactions with her students at the beginning of the class guarantee the success of her previous class. That is her success is not guaranteed by students' developing their interest and curiosity in new topics, but by recalling the knowledge learned in the previous classes. Interestingly, she stated that asking knowledge questions and giving the right answers, or right/wrong judgments on what students understand from previous class serve as the only way to start what she called the inquiry lessons.

Another representative example was Teacher Kung's teaching on solar and lunar eclipses. Before introducing new tasks to students, she posed knowledge questions to review the previous lesson to students, expecting students to provide right answers. However, her students did not get back to her with the answers she was expecting. Thus, she gave them a short explanation of previously learned lesson and moved on to explain the details of new hands-on activity — without setting a scientifically oriented question or allowing them to get curious about this new topic. This is shown in the following conversation:

Teacher Kung: Because you have already learned about the solar and lunar eclipse, I have some questions for you. How many types of solar and lunar eclipses are there? And how the position of the observer on Earth affects the view of a solar eclipse and lunar eclipse?. [ pointed to the picture on the screen] Do you remember this picture? What is this?

Student: Solar eclipse

Teacher Kung: Really?...Let's review what we have previously learned again. Do you remember that a solar eclipse occurs when the Sun, Moon, and Earth are aligned... The next activity is to study constellations. I want all of you to divide into a group of 5-6 people. Then, please study the procedure in the worksheet...

Here, although her open-ended questions seemed to allow and provoke students to elaborate the previously learned knowledge, her interactions exclusively focused on students' remembrance of previously learned knowledge and solicited right answers from them, rather than encouraging them to reason more deeply and connect what they learned to new topics they were going to learn in that class. Her actions seemed to have made her students turn off their sense-making of what they were going to do in the next activity.

In her interview, she stated that proposing the questions at the beginning of the classroom merely aims to access students' understanding of what they previously learned and confirm the success of her last class, and, if necessary, give correct explanations to students. She said, "Before introducing new lessons, asking review questions helps teachers survey what students got from my previous lesson. This allows me to give accurate answers on the spot when students got lost." This indicates that she seemed to believe that helping students remember facts and giving correct explanations on the spot is sufficient to invite students into new lessons, rather than eliciting their interest or grounding the activity in their experiences in order to have them ready for an inquiry-based activity in science.

As in the above examples, the teachers' belief on the certain way of providing feedback and providing the accurate answers to the review questions functioned to lead them to neglect the importance of questioning used in scientific inquiries. Although their beliefs on asking knowledge questions to help students recall the knowledge in the beginning classes is needed for the inquiry-based activities, telling the correct answers to students and moving forward to new lessons without helping students set leading questions for new inquiries seemed to turn off students' interest and curiosity in science. 
Pre-service Teachers Believed that Hands-on Activities are Avenues to Help Students Make Sense of What Teachers Explained to Them

In this research, it was revealed that most pre-service teachers often had students engage in hands-on activities before or after explaining the main concepts to them. When we interviewed them, they seem to have believed that having students engage in hands-on activities is essential to help students make sense of what the teachers told them as the activities provided students with concrete experiences.

A representative example of this was a hands-on activity implemented in Teacher Maew's lesson on phases of the Moon. She had her students engage in a demonstration session to simulate the change of the Moon's orbital positions around the Earth. In one cycle of the activities, two students were asked to act as the Earth and the Moon. To fulfill the basic elements of this phenomenon, a spotlight was utilized as the Sun - the light source of this activity. The student performing as the Earth was assigned to observe the change of student performing as the Moon while he/she was moving around (Figure 1). This simulation activity was repeatedly performed until all students got the opportunity to behave as the Earth, and to observe the change of the Moon. Here, all students were provided with opportunities to conduct investigations by themselves so that they can create their own understandings around the results of their explorations, as well as connect their experiential knowledge to their concrete experiences.

After finishing this activity, Teacher Maew had a few students explain what they observed, but she explained all main concepts to students without helping them think about why the shape of the Moon changes over time when viewed from the Earth. Although the hands-on activity was included in her science lessons, it was not done to elicit students' construction of their own explanation. Instead, it was done to help students confirm what the teacher told them in terms of concrete experiences. It is different from what we expected of even the lowest level of inquiry - a confirmatory inquiry — because students' explorations of ideas in hands-on activities were not used to help students construct scientific explanations.

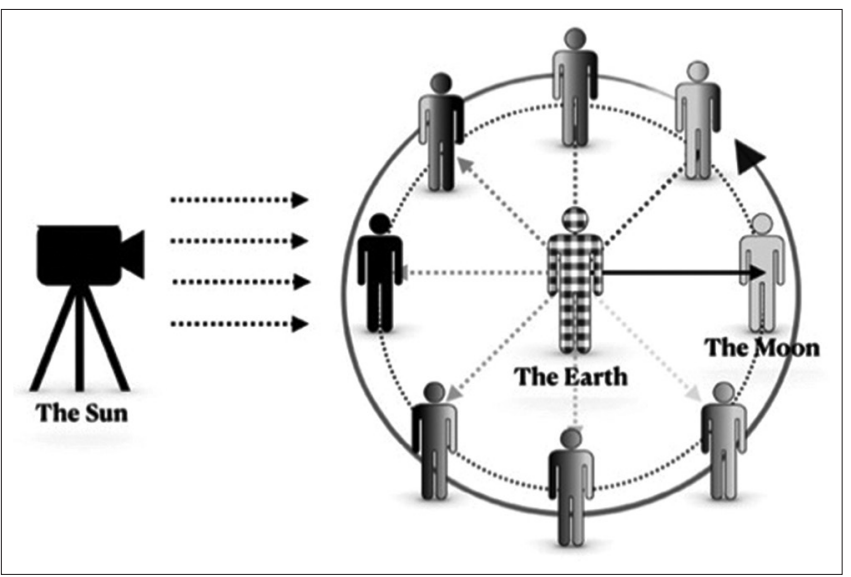

Figure 1: A role-playing in Teacher Maew' lesson
Interestingly, when we interviewed her after the lesson, she expressed her beliefs that a teacher should play an important role in transmitting knowledge to students, helping them reach the overall goal of the hands-on activities. She said, "Having done the activities by students alone cannot help students learn the concepts successfully. It is essential to tell them again what they should know." Her interview also indicated that hands-on activities were essential to increase students' understanding of what the teacher told them in terms of concrete experiences. She said, "Seeing and doing by themselves helps students understand how the concepts come about." However, in the actual learning activity, she served as a provider of the concept. Based on these, it could be inferred that she believed the hands-on activity was merely an activity to strengthen the teacher's transmission of knowledge, rather than an activity to help students build their understandings about science. Due to this purpose of hands-on activity, it can be conjectured that no spirit of inquiry existed since her students did not have enough opportunities to think about what they had explored.

Teacher Kai seemed to hold the same belief. In her practices of a spherical mirror (concave and convex) lesson, she initiated her lesson by telling what students should know the characteristics of the concave and convex mirror and the theory of light reflection by these mirrors. Then, she had them engage in the experiment to help them concretely understand the concepts she had talked about. In this experiment, students were assigned to start from draw the mirror line of the cylindrical mirror and locate its center of curvature by drawing the principal axis. Then, they were asked to notice the path of the reflected beam from the concave and convex cylindrical mirror (Figure 2). Although the steps of her teaching looked different from Teacher Maew' practices, her actions seemed to reflect the same kind of belief that scientific learning must be centered around the teacher's telling rather than students' explorations of ideas in hands-on activities. Again, her handson activity seemed to serve its intended function and through a concrete experiment, her students dutifully confirmed what they were told. Here, her lesson did not support students to construct their own explanations based on the findings - or to address scientifically oriented questions.

In the interview with her, she said, "Conducting an activity helps children understand more, after listening to the lecture since they got the opportunities to see and touch concrete materials. Pictures they see and direct feeling they have can increase their long-term memories." This illustrates her belief: an inquiry-based lesson is merely an activity to consolidate students' understanding of the knowledge the teacher handed down; not an activity to elicit students' interests and curiosity in science. This tells us that she was not igniting the spirit of inquiry among her students even though her students themselves conducted the investigation. Yet, the investigation is also handed down.

As in the above examples, this study illustrates that the teachers' belief in the purpose of hands-on activities served 


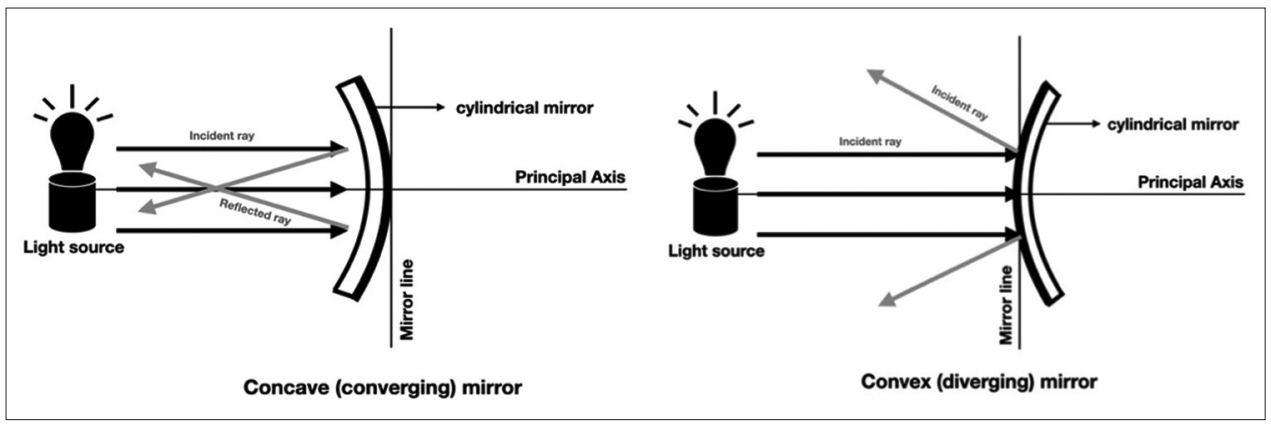

Figure 2: An experiment of the concave and convex mirror in Teacher Kai' lesson

as a key factor to downgrade the quality of hands-on activities in their inquiry lessons. It can be conjectured that the teachers believed that their students themselves would not be able to construct scientific concepts around their findings during hands-on activities.

Pre-service Teachers Believed that Providing Clear, Procedural Instructions to Students is an Effective Approach to Help Them Build their Understanding and Eliminate Out-of-Control Classroom Situations

The research findings indicated that in many of the six preservice teachers' lessons, their students were required to follow prescribed steps given by teachers while engaging in hands-on activities. When we interviewed the teachers, they often stated that giving a procedural task to students allowed them to check whether they were doing the right things. This also helped the teachers prevent unpredictable classroom situations that they might not know how to cope with.

A representative example of this was how Teacher Kai have her students engaged in the hands-on activity. Before having students conduct the experiments of forming an image by a spherical mirror (Figure 2), she first had them recite the experimental procedures from the textbook. After that, she explained the procedures briefly and asked questions, "Could you tell me what equipment is needed for this experiment?" and "Could you tell me what you need to do first?" to confirm whether the students understood what they needed to do. This is done without helping students make sense of the experimental design and its purpose. After her students had completed each step of the task, she asked them for a "check-in" conversation with her confirmation questions, for example, "Have you already drawn the principal axis and mirror line?" Since her students dutifully reproduced all of what she told them to do in the experiment and she did not ask them to think deeply about why they needed to do those steps, it can be conjectured that they might not be able to clearly understand the purpose of the experiment and what they should observe - or what they were looking for in the experiment even though they engaged in a hands-on activity.

Looking more closely, the interview revealed that despite her clear instructions, she believed some students would still be confused about how to start an experiment or what was being asked of them. She believed a step-by-step instruction on the hands-on activity, provided in the required and commonlyused Thai science books, can help all students build their understanding of the main concepts in the same way. She said, "Students should follow what the teachers impose so that they can discover correct results... and not get lost in a multi-part activity." In addition, she pointed out that this can prevent unanticipated classroom situations that could occur when they mixed up the given experimental steps. She said, "If we do not want them to do things in the wrong order that might be difficult to cope with, following and checking are the best way to protect it." This expression reflects that her instructional practices seemed to be underlined by her belief in making sure that students do not deviate from the given instructions. Also, it can be conjectured that she did not believe in her students' ability to delve into the targeted concepts while engaging in their designed strategies during the scientific investigations. Being an inexperienced teacher, she was still worried about making sure things go as expected - do not go into a chaos, which then force her to deal with uncertainty (e.g., students' getting lost in the activity and do not know what to do). The craving for certainty inevitably led her to give clear instructions to students.

Another example was Teacher Chang's lesson on heat transfer - the transfer of heat through a liquid from a warmer spot to a cooler spot. He started his classroom investigation of the convection in a liquid by showing how to use lab equipment and explaining how to conduct the experiment. He did so without having students set their own goals or strategies for conducting the scientific investigation. He then demonstrated the experiment and showed the right/accurate - the expected — results in which their students will later be judged against. After that, his students began conducting the experiment on their own and were asked to observe the occurrence of convection when heating potassium permanganate in water (Figure 3). As his students began to work, he walked around the classroom to explain to his students what their results meant and gave an evaluative comment on their results. It could be inferred that he believed students understand the main concepts when expected and correct results occur, and this is the only case. Consequently, the students were asked to follow the rigid procedure the teacher had set to obtain these correct results.

While interviewing him, it seemed that his instructional practices were based on his beliefs that exposing students 


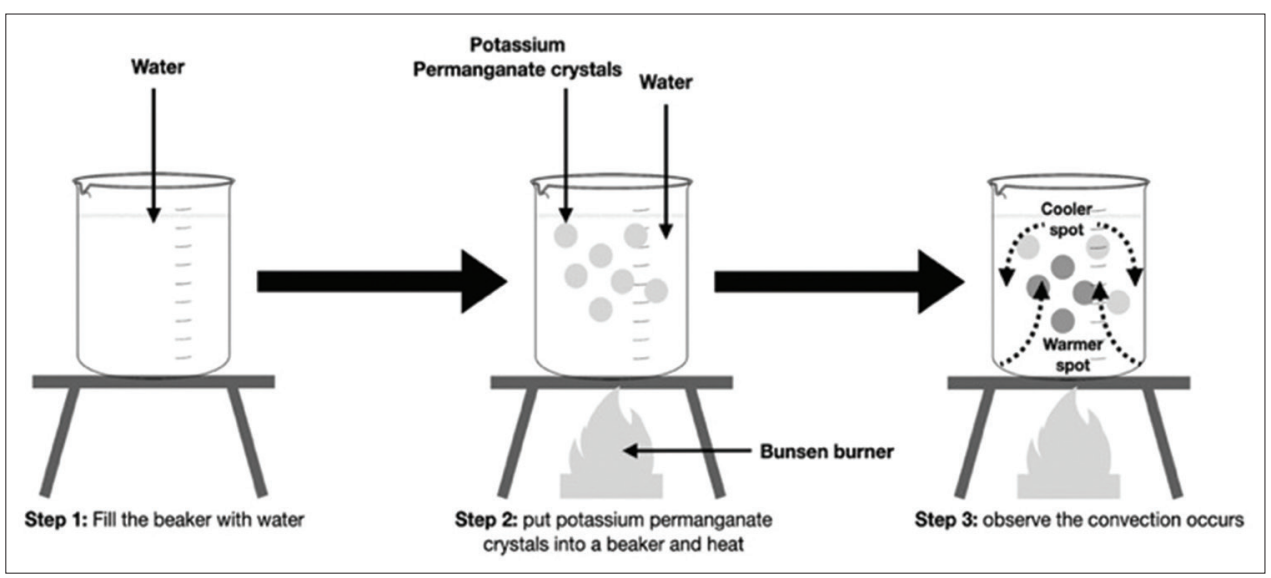

Figure 3: An experiment of the convection in a liquid

to clear instructions and providing a demonstration on how to accurately conduct the experiment were essential to help students make sense of knowledge handed down from the teacher as they would have concrete experiences. He said, "Supporting students to build their own understanding of science consists of giving an explicit demonstration and stepby-step instructions. These avenues can minimize the chance of teachers' losing control of their classes and students can learn from the correct results." Based on this statement, it could be inferred that his fear of losing class control served as the reason why he gave rigid experimental procedures to students.

The above examples inform us that the teachers' beliefs on giving the right procedural instructions because of their fear of losing class control, functioned to devalue how students engaged in hands-on activities in inquiry-based lessons. The activities simply serve as a way of gathering information. They seemed to believe that they cannot help students make their own discoveries so that they truly and autonomously understand science.

Pre-service Teachers Believed that Teachers' Drawing an Evidence-based Conclusion and Connecting Explanations to Scientific Knowledge are Sufficient to Help Students Make Sense of What they Observed in Hands-on Activities. This way, Students Understand Scientific Concepts. Assisting Students to Build Consensus on the Conclusion is Not Necessary

We found that after pre-service teachers provided students with concrete experiences by engaging them in hands-on activities, they often gave the final scientific explanation to students, based on different evidence obtained in their students' investigation. When we interviewed the participant teachers, they stated that scientific explanations and concepts should be grounded on evidence obtained in the hands-on activities, and should be given by the teachers. Almost all lessons observed in this study belong to this category.

Take Teacher Chang's teaching on heat transfer, for example. After his students engaged in the hands-on activities, he asked them to come up to the front of the classroom and share the results they had investigated with their classmates as if he was about to start the whole-class discussion. However, when he heard the students' results, he wished to hear, he immediately uttered "Correct" and "Yes" as a reply to those answers. He then explained the underlying concepts to students, as shown in the following conversation:

Student Group A: When we put the potassium permanganate crystals into a beaker of heated water, we found that the water became colored water. It turned to the violet water.

Teacher Chang: Correct! How about the motion of the colored water?

Student Group A: We saw the potassium permanganate crystals moved up and down.

Teacher Chang: Yes! It is because the potassium permanganate crystals would move up when its particles were heated up. It would take energy from the heater to the top of the water and back down when they were cold. This was what happened till the whole water became colored and had the same heat energy. It calls heat transfer.

According to the above conversation, it tells us that although his students were provided with the opportunity to present the results from their exploration, they did not learn to reason on their own about what they observed in the inquiry-based activity. Teacher Chang readily gave evaluative comments to students' findings and explained how their results were related to scientific concepts. This was done without asking the students to notice some common findings or differences among classmates so as to help them polish their scientific assumptions. This tells that he simply checked what students observed in the hands-on activity before narrating the summary to them.

In the interviews with Teacher Chang, it confirmed that his beliefs indeed underpin his teaching method. He stated that students should be given enough opportunities to present what they had explored during the hands-on activities. He also stated that it helps him check what students had been doing during the hands-on activities. This gets them ready to acquire the 
teacher's final explanation related to scientific concepts. He said, "If students do not present what they get, I cannot know whether what they got from hands-on work is correct. They might later feel confused when I gave them the conclusion." Here, this confirms his belief that having students present their discoveries would serve as an avenue to have them ready for receiving the explanations from the teacher. He seemed to not believe in orchestrating students' discussions on evidence gathered during the hands-on activities, or in allowing students to conclude the lesson so they can make connections between concepts learned in the activities and its underlying scientific concepts.

Another example is in Teacher Kung's giving a conclusion to her students. In her lesson on the food web and food chain, her students were asked to engage in role-playing as various organisms in the ecosystem - which were decided randomly by the prepared index cards. Students were required to imagine themselves as each organism, and think about what organisms they eat and what organisms consume them. Once a chain was formed using the rope passing from one student to another, the chain ended when the rope was passed back to the Sun. All students were provided with opportunities to explore interactions among various organisms that form food chain and food web by themselves. They understood how energy flows through food chains and food webs, and modeled the interrelationships in ecosystems. After this activity, without eliciting students to build their own explanations of what they discovered in the role-playing session, she provided students with the well-constructed explanation of ecological relationships. This showed that the teacher served as a sole key person in giving a conclusion and connecting it to the intended scientific concepts.

In the interviews, Teacher Kung stated that directly telling the correct and well-constructed scientific summary to students was essential to help students build understanding around the topic. She said in post-interview, "Students have a better understanding how energy flows through food chains and food webs by listening to my lecture... they got the opportunity to see by themselves, which followed by listening to the correct and clear scientific explanations. "To us, she seemed to believe that exposing students to her own explanation of scientific concepts will help her students make sense of what they did in the hands-on activities, rather than encouraging them to construct their own explanations.

As in the examples shown above, the teachers' beliefs in telling students how they should interpret what they witnessed in inquiry activities seems to have adversely affected the ongoing changes in students' meaningful thinking about science, despite the fact that they themselves engaged in the activities. It can be assumed that the teachers believed that their students were not able to relate the ideas they had explored - while engaging in the activities, to a more complex and correct scientific explanations.

\section{DISCUSSION, CONCLUSION, AND IMPLICATION}

Based on the results previously discussed, it seems that the fundamental problems observed in many pre-service teachers' teaching stemmed from their existing beliefs on teaching science as inquiry. Although teachers' beliefs are invisible and cannot be evaluated at the surface, they seem to have been always actively underlying teachers' actions during the lessons. In a way, they served as "silent antagonists" hindering the effective implementation of inquiry-based science lessons since they functioned against students' curiosity and interest in scientific inquiries and what the inquiry-based lessons attempted to achieve. Scrutinizing a teacher's belief, we must go below the surface. Pajares (1992) stated that teachers' beliefs can be understood through their words and actions. This study evidenced that the beliefs can be revealed through classroom observations and open-ended interviews with the teachers.

This study also found that even if inquiry-based teaching was encouraged in teacher training program and many pre-service teachers seemed to agree on its significance, their science lessons did not show the spirit of inquiry. Here, it evidenced that teachers' beliefs could offer a greater insight into their actions than their knowledge and understanding. These beliefs serve as a filter in knowledge interpretation (Nespor, 1987; Pajares, 1992). These beliefs can be revealed by making inferences from individuals' underlying statements and actual behaviors during their lessons.

On a closer inspection, we found that several of the preservice teachers' beliefs about the inquiry-based lessons not only lowered the students' inclination to participate in the classes but also devalued their sense of interest and curiosity in science, which in turn might obstruct their new learning (Galili et al., 1993).

First, although the pre-service teachers often asked students knowledge questions to help them review the previously learned knowledge, they immediately gave away the answers or gave their judgments on whether their student's responses were right. Consequently, students who contributed the answers were not encouraged to reason deeply about their inaccurate or accurate answers. As a result, it can be conjectured that their sense of interest and curiosity in science got turned off in the lessons.

Secondly, too much of a focus on confirming their students' knowledge resulted in the teachers' problematic understanding of inquiry-based lessons. They failed to help students develop any scientifically oriented questions and to help them consider the underlying reasons in conducting the investigation. Therefore, it is considered to be fundamentally different from even the lowest level of inquiry - the confirmatory inquiry lesson - in which students are assigned to go through the provided procedure, record the results as indicated, and answer the provided questions on their own (Bell et al., 2005). This 
level of inquiry can help students see the intrinsic reward of learning through using their critical thinking and investigation skills. Thus, the confirming students' knowledge, evidenced in this study, does not amount to so-called a confirmatory inquiry lesson. Recalling what the teachers told them, students did not develop the inquiry skills.

Thirdly, pre-service teachers were trapped in their fear of losing control of their classrooms. To avoid the uncertainty of classroom situations, they usually controlled students' engagement, by providing students with cookbook-like activities, giving them scientific explanations, and making students agree with the teachers' opinions. Inoue and Buczynski (2011) reported a similar finding that novice teachers had a tendency to focus on their own actions, rather than students' actions due to the fear of losing classroom control. This indicated the interaction between the teachers' actions and their beliefs.

Furthermore, this study revealed that pre-service teachers found it difficult to facilitate class discussions. As is often the case in novice teachers' inquiry-based lessons, they failed to push students' classroom presentations to go beyond the Show-and-Tell activities in which students represent and receive teachers' judgments on their results. Their students were not invited to be a part of the whole class building consensus on scientific explanations in reference to comparing diverse ideas with their peers and connecting them to scientific concepts (Lampert, 2001; Stein et al., 2008). The study found that teachers' beliefs were functioning behind these actions: teachers' providing students with cookbook-like activities due to their fear of losing classroom control, tendency to overexplain scientific concepts, and failing to consider students' curiosity and interests, seem to have been interacted with their beliefs. This implies the necessity to help the pre-service teachers learn the "balancing act"- the balance between the non-authoritative transfer of responsibility and the facilitative leadership to bring students toward achieving the lesson goal; a necessity for the effective teaching of inquiry-based lessons (Inoue, 2011; Inoue et al., 2019).

Particularly, we learned that there was the complexity in delineating the roles of teachers' beliefs in inquiry-based lessons exemplified by the possible dialectic relationship between belief and fear. Teachers' beliefs could be an effective tool to track the teachers' progress in implementing future inquiry-based lessons (Mansvelder-Longayroux et al., 2007). Teachers plan their inquiry instructions on the grounds of their fear that stemmed from their beliefs of effective classroom inquiry. Their actual practices also reconstruct their own theoretical knowledge of instruction and represent the enaction of a newly developed belief of effective inquiry lessons (Tillema, 2002).

It would be important that pre-service teachers reflect on their beliefs through developing a lesson plan, delivering the planned lesson, reflecting on it, and improving it in cyclic manners. It would be beneficial to support their participation in "the reflection process" to clarify and reflect on their beliefs system from their own teaching. One possible avenue to actualize such a support would be to have teachers engage in "Japanese lesson study" in which teachers do not simply talk about the lessons but they reflect on their own lessons. It will help them look deeply into their belief system and their relationships to teaching, and transform it systematically on their own (Takahashi, 2014; Inoue et al., 2019). A new systematic study would be needed to further pursue this issue.

To conclude, the findings of this study can be seen to shed a new light on what kinds of help pre-service teachers need for learning to teach inquiry-based lessons effectively. Particularly, their fear of losing control of their classroom seems to have shaped their belief about science teaching. Experienced teachers may not have such fear that influences how they approach their inquiry teaching, but pre-service teachers would greatly benefit from being helped overcoming such fear and shape their belief on science teaching in teacher education programs. For example, pre-service teacher education would benefit from being offered ample opportunities to reflect on this "fear" factor and a possible dialectic relationship between their fear, belief, and actual teaching practice in their classrooms in lesson study dialogues. It would be beneficial to conduct follow-up studies and analyze in greater depth how such reflective activities could help pre-service teachers overcome their fear and shape their belief that positively impact their inquiry-based teaching. Through such effort, it would be possible to inform, strengthen, and pave the way for better teacher preparation and teacher professional development programs.

\section{REFERENCES}

Antoniadou, P., \& Skoumios, G.M. (2012). Primary teachers' conceptions about science teaching and learning. Science in Society, 4, 69-81.

Bell, R.L., Smetana, L., \& Binns, I. (2005). Simplifying inquiry instruction. The Science Teacher, 72(7), 30-33.

Capps, D., \& Crawford, B. (2013). Inquiry-based instruction and teaching about nature of science: Are they happening? Journal of Science Teacher Education, 24(3), 497-526.

Crawford, B.A. (2000). Embracing the essence of inquiry: New roles for science teachers. Journal of Research in Science Teaching, 37, 916-937.

Galili, I., Bendall, S., \& Goldberg, F. (1993). The effects of prior knowledge and instruction on understanding image formation. Journal of Research in Science Teaching, 30(3), 271-301.

Ginsburg, H. (1997). Entering the Child's Mind: The Clinical Interview in Psychological Research and Practice. Cambridge, United Kingdom: Cambridge University Press.

Hansen, B., Buczynski, S., \& Plunkett, K. (2015). Curriculum and Instruction for the $21^{\text {st }}$ Century. Arizona, United States: Bridgepoint Education.

Inoue, N. (2011). Zen and the art of neriage: Facilitating consensus building in mathematics inquiry lessons through lesson study. Journal of Mathematics Teacher Education, 14, 5-23.

Inoue, N., \& Buczynski, S. (2011). You asked open-ended questions, and now what?: Understanding the nature of stumbling blocks in mathematical inquiry lessons. Mathematics Educator, 20, 10-23.

Inoue, N., Asada, T., Maeda, N., \& Nakamura, S. (2019). Deconstructing teacher expertise for inquiry-based teaching: Looking into consensus building pedagogy in Japanese classrooms. Teaching and Teacher Education, 77, 366-377.

Kang, E.J.S., Bianchini, J.A., \& Kelly, G.J. (2013). Crossing the border 
from science student to science teacher: Preservice teachers' views and experiences learning to teach inquiry. Journal of Science Teacher Education, 24, 427-447.

Keys, C.W., \& Bryan, L.A. (2001). Co-constructing inquiry-based science with teachers: Essential research for lasting reform. Journal of Research in Science Teaching, 38, 631-645.

Krajcik, J. (2015). Three-dimensional instruction. The Science Teacher, 82(8), 50-54.

Kuhn, D. (1993). Science as argument: Implications for teaching and learning scientific thinking. Science Education, 77(3), 319-337.

Lampert, M. (2001). Teaching Problems and the Problems of Teaching. United Kingdom: Yale University Press.

Lederman, J.S., Lederman, N.G., Bartos, S.A., Bartels, S.L., Meyer, A.A., \& Schwartz, R.S. (2014). Meaningful assessment of learners' understandings about scientific inquiry-the views about scientific inquiry (VASI) questionnaire. Journal of Research in Science Teaching, 51(1), 65-83.

Mansvelder-Longayroux, D.D., Beijaard, D., \& Verloop, N. (2007). The portfolio as a tool for stimulating reflection by student teachers. Teaching and Teacher Education, 23(1), 47-62.

Minner, D.D., Levy, A.J., \& Century, J. (2010). Inquiry-based science instruction-what is it and does it matter? Results from a research synthesis year 1984 to 2002. Journal of Research in Science Teaching, 47(4), 474-496.

Muhtarom, M., Juniati, D., \& Siswono, T.Y.E. (2019). Examining prospective teacher beliefs and pedagogical content knowledge towards teaching practice in mathematics class: A case study. Journal on Mathematics Education, 10(2), 185-202.

National Research Council (NRC). (1996). National Science Education Standards. United States: National Academies.

National Research Council (NRC). (2000). Inquiry and the National Science Education Standards: A Guide for Teaching and Learning. United States: The National Academies Press.

Nespor, J. (1987). The role of beliefs in the practice of teaching. Journal of Curriculum Studies, 19, 317-328.

Nott, M., \& Smith, R. (1995). Talking your way out of it, 'rigging' and 'conjuring': What science teachers do when practicals go wrong. International Journal of Science Education, 17(3), 399-410.

Pajares, M.F. (1992). Teachers' beliefs and educational research: Cleaning up a messy construct. Review of Educational Research, 62(3), 307-332.

Saad, R., \& BouJaoude, S. (2012). The relationship between teachers knowledge and beliefs about science and inquiry and their classroom practices. Eurasia Journal of Mathematics, Science and Technology Education, 8(2), 113-128.

Sandoval, W.A., \& Reiser, B.J. (2004). Explanation-driven inquiry: Integrating conceptual and epistemic scaffolds for scientific inquiry. Science Education, 88(3), 345-372.

Stein, M.K., Engle, R.A., Smith, M.S., \& Hughes, E.K. (2008). Orchestrating productive mathematical discussions: Five practices for helping teachers move beyond show and tell. Mathematical Thinking and Learning, $10(4), 313-340$.

Takahashi, A. (2014). Supporting the effective implementation of a new mathematics curriculum: A case study of school-based lesson study at a Japanese public elementary school. In: Li, I.Y., \& Lappan, G., (Eds.), Mathematics Curriculum in School Education. Berlin, Germany: Springer. pp. 417-441.

Tatar, N. (2015). Pre-service teachers' beliefs about the image of a science teacher and science teaching. Journal of Baltic Science Education, 14(1), 34-44.

Tillema, H.H. (2000). Belief change towards self-directed learning in student teachers: Immersion in practice or reflection on action. Teaching and Teacher Education, 16(5-6), 575-591.

Tondeur, J., van Braak, J., Ertmer, P.A., \& Ottenbreit-Leftwich, A. (2017). Understanding the relationship between teachers' pedagogical beliefs and technology use in education: A systematic review of qualitative evidence. Educational Technology Research and Development, 65(3), 555-575.

Windschitl, M., Thompson, J., \& Braaten, M. (2018). Ambitious Science Teaching. United States: Harvard Education Press.

Windschitl, M., Thompson, J., Braaten, M., \& Stroupe, D. (2012). Proposing a core set of instructional practices and tools for teachers of science. Science Education, 96(5), 878-903. 